ELORE (ISSN 1456-3010), vol. 18 - 2/2011.

Julkaisija: Suomen Kansantietouden Tutkijain Seura ry.

[http://www.elore.fi/arkisto/2_11/hovi.pdf]

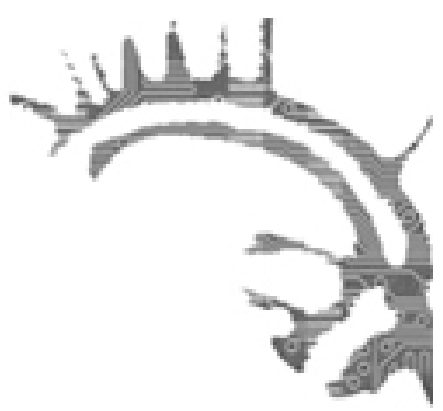

\title{
KIRJA-ARVIO
}

\section{KOHERENSSIN TUOLLA PUOLEN}

HYVÄRINEN, MATTI \& HYDÉN, LARS-CHRISTIAN \& SAARENHEIMO, MARJA \& TAMBOUKOU, MARIA (eds.) 2010: Beyond Narrative Coherence. Studies in Narrative 11. Amsterdam: John Benjamins Publishing Company. 196 sivua.

\section{Tuija Hovi}

Tämäkin kertomus alkaa Aristoteleestä kuten niin moni muu ennen tätä. Alku, keskikohta ja loppu on kaava, jonka jo muinaiset kreikkalaiset oppivat kuuluvan "hyvään kertomukseen".

Yhteensopivuus, yhtenäisyys, kiinteys eli koherenssi tai sen luominen koettuun on yleisesti nähty kertomuksen tärkeäksi funktioksi. Tästä syystä ymmärrys koherenssista on lähtökohtaisesti arvottava, toteaa Beyond Narrative Coherence -artikkelikokoelman kansainvälinen toimittajaryhmä, Matti Hyvärinen, Lars-Christian Hydén, Marja Saarenheimo ja Maria Tamboukou. Yleensä ihmisen ajatellaan elävän laadukkaampaa elämää, jos hänellä on koherentti elämänkertomus ja siitä seuraava koherentti identiteetti. Narratiivisen koherenssin arvo on korostunut, koska elämä sinänsä on ymmärretty pikemminkin sattumanvaraisena ja vailla hallittavaa muotoa olevana.

Esimerkiksi Galen Strawson (2004) on ohjelmallisella artikkelillaan pyrkinyt tämän arvottavan ymmärryksen purkamiseen ja kyseenalaistamiseen. Strawsonin analyysi perustuu kuitenkin lähinnä moraalifilosofiaan ja kaunokirjallisuuteen, ei puhuttuun arkikieleen. Hän liikkuu siis eri kentillä kuin esimerkiksi kokemuskerrontaa tutkivat folkloristit tai sosiaalipsykologit. Puhuttujen aineistojen kanssa työskentelevillekin kysymys koherenssista on silti pohtimisen arvoinen. Hyvärinen kumppaneineen toteaa koherenssin arvostuksen marginalisoivan tutkimukselta monta kerronnallista ilmiötä, nimenomaan "luonnollisesti syntyvät kertomukset". Toimittajat propagoivat esipuheessaan paradigman muutosta kerronnan tutkimuksessa ja vertaavat uutta koherenssinäkemystä narratiiviseen käänteeseen 1980-luvulla - paradigmaan, jossa koherenssi on monella tasolla ollut nimenomaan hyve. 


\section{SOSIAALIPSYKOLOGIT KERTOMUSTEN PARISSA}

Kokoelman kirjoittajat edustavat pääasiallisesti yhteiskunta- ja käyttäytymistieteilijöitä ja ovat kukin tahoillaan tehneet narratiivista tutkimusta. Artikkeleissa kritisoidaan ja työstetään kerronnallisen koherenssin käsitettä teoreettisesti, metodisesti ja eettisesti. Kirjoittajat ovat nyt lähteneet tutkimaan myös sellaisia kerronnallisia muotoja, jotka eivät sovi vallitsevaan ihanteeseen narratiivisesta koherenssista. Kirjan sanoma on se, että koherenssissa olisi pyrittävä ymmärtämään sen monimuotoisuus.

Toimittajat esittävät esipuheessaan myös kiintoisan kysymyksen: voiko koherenssista olla vahinkoa? Heidän mukaansa vahinkoa siitä kapeasti ymmärrettynä koituu nimenomaan tutkimukselle. Ensinnäkin voidaan priorisoida "hyviä kertomuksia". Hyvien kertojien ja ehyiden kertomusten metsästyshän on perinteisesti kuulunut folkloristiikkaan. Hyvän kertomuksen tavoite voi myös vääristää lukustrategiaa. Se voi niin ikään kaventaa kerrontaa sinänsä - tuotetaan vain sitä mitä halutaan kuulla. Vaihtoehtoista kuvakulmaa kerrontaan Beyond Narrative Coherence -kirjan artikkeleissa etsitään tilannekohtaisuuden, kokemuksellisuuden, ymmärrettävyyden ja kerrottavuuden kautta.

Maria I. Medved ja Jens Brockmeier ovat tutkineet aivovammapotilaiden kertomuksissa minuuden rakentumisesta ilman koherenssia tai puutteellisella koherenssilla. He pohtivat aristoteelisen ja diskursiivisen koherenssin suhdetta ja vastakkaisuutta. Aristoteelinen standardi on liian kapea "murtuneen kertomuksen" tarkastelussa, sen sijaan diskursiivinen ja sosio-kulttuurinen näkemys on siinä toimivampi. Kirjoittajat tuovat mukaan käyttökelpoiselta kuulostavan käsitteen kontekstuaalinen koherenssi ja kritisoivat näkemystä, jonka mukaan identiteetti olisi vain kielellinen, narratiivinen abstrakti konstruktio. Henkilökohtaiseen jatkuvuuden kokemukseen sisältyy myös koko arkikommunikaation diskursiivinen verkosto.

Merkityksenanto on toki koherenssin luomista, mutta koherenssi ei ole sama kaikille. Lars-Christian Hydén esittää, että kerronnassa muut seikat kuin koherenssi voivat olla identiteetille tärkeämpiä. Autobiografia kertomustyyppinä on paradigmaattinen sairaskertomusten tutkimuksessa. Haastattelussa tuotettuna se poikkeaa "luonnollisista" kerrontatilanteista. Silti identiteetti on yhdistetty henkilön kykyyn kertoa elämänkertomus. Hydén kuitenkin osoittaa, että sisältö ei ole tärkeä vaan se, kuka kertoo, milloin ja kenelle. Kysymys on pikemminkin kerrottavuudesta (engl. tellability) ja asian ytimestä, syystä kertoa (engl. point) kulloisessakin kerrontatilanteessa, mihin myös arkikerrontaorientoituneet folkloristit ovat huomionsa kohdentaneet.

Tarja Aaltonen yhdistää keskustelun analyysin kognitiiviseen narratologiaan puhuessaan mielenlukemisesta (engl. mind reading) ja tarinamaailmasta (engl. storyworld) afasiapotilaiden kuntoutuksessa. Lähtökohtana on se, että ilmaisu ja tapa, jolla se ilmaistaan ei ole ymmärrettävä sen sosiaalisen kontekstin ulkopuolella, jossa se on tuotettu. Esimerkkianalyysi Tikoteekki-tapauksesta kuvastaa hyvin tilanteen lukemisen haasteellisuutta ja sitä, kuinka tulkitsija ei selviydy pelkän katkonaisen puheen varassa vaan hänen on tunnettava myös tulkittavan elämänhistoriaa ja tapaa ajatella. 
Tuija Hovi: Koherenssin tuolla puolen

\section{TAIDE, TRAuma JA KERRONTA}

Maria Tamboukou on tutkinut murtuneita kertomuksia walesilaisen taiteilijan, Gwen Johnin kirjeiden ja maalausten pohjalta. Keskeisiä käsitteitä ovat aikaperspektiivi ja nomadinen subjekti. Tamboukoun artikkeli on kokoelmasta lähimpänä narratologiaa soveltaessaan deleuziläistä analyysiä tapahtuman ja kuvauksen suhteeseen. Taiteen parissa liikkuu myös Linda Sandino, jonka aiheena on narratiivisen identiteetin jäljitys. Hän määrittelee elämänkertomuksen avustetuksi narratiiviksi (egl. assisted narrative), autobiografian ja biografian välimuodoksi. Taiteilijuuden rakentuminen on prosessi, joka tapahtuu ikääntymisen myötä. Sandino tarkastelee sitä Ricoeurin malliin istuttaen, prefiguraation, konfirmaation ja refirmaation vaiheiden kautta. Koherenssin luomiselle keskeinen taiteilijankin "kääntymiskertomuksessa" on epifania eli käännekohta.

Vilma Hänninen ja Anja Koski-Jännes ovat tarkastelleen minä-kerronnan tietoista rikkomista uudelleen orientoitumisena elämään. ”Hyvän kertomuksen” paradigmalle vastakkaisesti inkoherenssi voikin joissakin tapauksissa olla hyvä ja funktionaalinen strategia. Se toimii negatiivisen menneen taakse jättämisen keinona. Kirjoittajat käsittelevät kysymystä alkoholistihoidon kontekstissa. Tyystin strawsonilaiselle "koherenssivastaiselle" linjalle he eivät kuitenkaan heittäydy, vaan suhtautuvat siihen harkitulla kritiikillä. Kirjoittajat esittävät aiheellisena kysymyksenä, kuka lopulta määrittelee koherenssin kerronnassa ja mikä on kokonainen autobiografia. Ehkä vastaus tässäkin löytyy tilannekohtaisuudesta.

Alison Stern Perez, Yishai Tobin ja Shifra Sagy ovat tarkastelleet israelilaisten bussikuskien kertomuksia terrori-iskuista. Kuljettajat joutuvat kehittämään omanlaisiaan selviytymisstrategioita työskennellessään jatkuvan väkivallan uhan alla. Perez kumppaneineen lähestyy teemaa diskurssianalyysin ja semiotiikan keinoin yhden esimerkkikertomuksen valossa. Keskeisenä analyysissä on kontekstuaalisuuden ymmärtäminen, yksilön, ajan, tilanteen ja ympäristön suhde. Molly Andrews on puolestaan paneutunut nonkommunikaatioon, kielen ja hiljaisuuden rooliin traumakertomuksissa. Hän tarkastelee artikkelissaan sitä, miten ilmaisemattomia kokemuksia käsitellään. Andrewsin mukaan henkilökohtainen tuska muuttuu kerrottuna "sosiaaliseksi kärsimykseksi", se ei ole enää pelkästään omaa. Traumatodistusta leimaavat murtumat eri tasoilla, niin koherenssissa, rakenteessa, merkityksessä kuin ymmärrettävyydessäkin.

\section{KOHERENSSIN VAPAUS}

Mark Freeman päättää kokoelman kaikkea edeltävää kommentoivalla artikkelillaan. Kuten hän huomauttaakin, joka artikkelissa on tavalla tai toisella esillä ilmeisen ei-koherenssin takana luuraava latentti koherenssi. Kaikki kirjoittajat siis lopulta tavalla tai toisella esittävät, että on olemassa jonkinlainen suhde yksilön hyvinvoinnin ja kerronnan koherenssin välillä. Määritelmä koherenssista tai hyvinvoinnista ei kuitenkaan ole vakio vaan yksilö- ja tilannekohtainen. Tiedon rakentuminen siitä on riippuvainen myös tutkijan tekemistä valinnoista. Toisaalla esimerkiksi Thomas 
Csordas kumppaneineen on antropologisin ottein havainnollistanut sitä vertaillessaan erilaisten haastattelumetodien vaikutusta kertomusten - ja koherenssin - tuottamiseen kansanlääkintää tutkivassa projektissa (ks. Csordas et al. 2010).

Freeman tarkentaa myös, että murtuneisuus kerronnassa ei ole sama kuin inkoherenssi. Mitä sitten on koherenssi? Freeman itse hyväksyy toimittajien ja kirjan lähtökohdan, sen että koherenssin käsite kaipaa uudelleenajattelua, sillä aristoteelinen näkemys on liian kapea. Mutta ovatko sekavat puheet narratiivinen teko? Voidaanko siis olla yhtä mieltä siitäkään, mikä on kertomus? Voiko narratiivia ajatella ilman koherenssia irrallaan klassisista kategorioista (alku - keskikohta - loppu)? Asiat eivät jäsenny aina elämässäkään niin somasti. Siispä hyväksykäämme se, että koherenssi voi asettua narratiiviin monella tavalla, tilanteesta ja tarkoituksesta riippuen. Koherensseista voi keskustella, niitä voi olla monia, eivätkä ne ole kiveen kirjoitettuja.

\section{KIRJALlisuUs}

CSORDAS, THOMAS \& DOLE, CHRISTOPHER \& TRAN, ALLEN \& STRICKLAND, MATTHEW \& STROCK, MICHAEL G. 2010: Ways of Asking, Ways of Telling. A Methodological Comparison of Ethnographic and Research Diagnostic Interviews. - Cult Med Psychiatry 34.

STRAWSON, GALEN 2004: Against Narrativity. - Ratio (new series) XVII(4).

Tuija Hovi on Suomen Akatemian tutkijatohtori ja työskentelee Åbo Akademin uskontieteen oppiaineessa. 